\title{
Investigation of the Attitudes of Academicians towards Sports
}

\author{
M. Fatih Karahuseyinoglu \\ Faculty of Physical Education and Sport Sciences, Firat University, Turkey. \\ Email: fkarahusevinoglu@gmail.com Tel:00905053459525
}

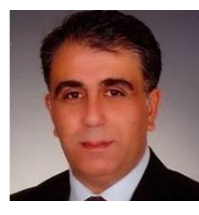

\begin{abstract}
The purpose of this study is to investigate the attitudes of academicians towards sports at Firat University, 191 academicians participated in the investigation as part of our study. "Attitude Scale towards Sports" was used to determine the attitudes of the academicians participating in the study towards sports. The scale is designed in likert type 5 grading, consisting of 22 substances and "Psychosocial, Physical and Mental Development" consisting of 3 sub-dimensions. In line with the study findings, academicians at Firat University have a general score of 1 to 5 scale scoring is $\overline{\mathrm{x}}=3.93$, "Mental Development" sub-dimension size is $\overline{\mathrm{x}}=3.53$, "Psycho-social Development" subdimension size is $\bar{x}=3.98$, and "Physical Development" sub-dimension size with an average of $\bar{x}=$ 4.08 was observed to have high attitude levels towards sports. There was a statistically significant difference in terms of attitude levels towards sports and age, participation in sports, title and working year variables for Academicians at Firat University. According to the gender variable, it was not found that the attitudes of academicians towards sports were not statistically significant. Academicians' attitudes towards sports are very important. Students often see their instructors as their cult figure. Academicians' attitudes towards sports are thought to make them feel good about themselves in terms of health and will be a positive example for students who consider themselves cult figures.
\end{abstract}

Keywords: Sports, Attitude, Academician, University.

Citation | M. Fatih Karahuseyinoglu (2019). Investigation of the Attitudes of Academicians towards Sports. Asian Journal of Education and Training, 5(4): 589-594.

History:

Received: 12 September 2019

Revised: 15 October 2019

Accepted: 21 November 2019

Published: 19 December 2019

Licensed: This work is licensed under a Creative Commons

Attribution 3.0 License (c))

Publisher: Asian Online Journal Publishing Group
Funding: This study received no specific financial support.

Competing Interests: The author declares that there are no conflicts of interests regarding the publication of this paper.

Transparency: The author confirms that the manuscript is an honest, accurate, and transparent account of the study was reported; that no vital features of the study have been omitted; and that any discrepancies from the study as planned have been explained.

Ethical: This study follows all ethical practices during writing.

\section{Contents}

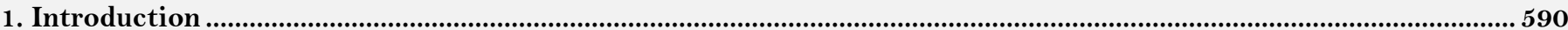

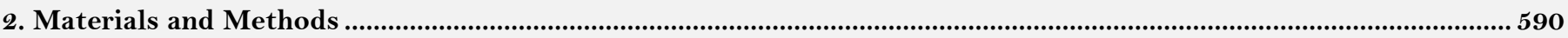

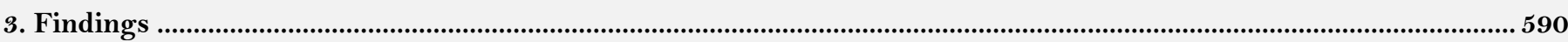

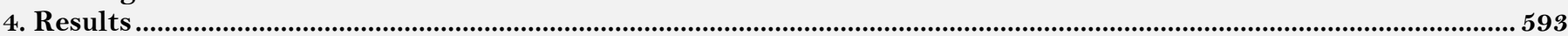

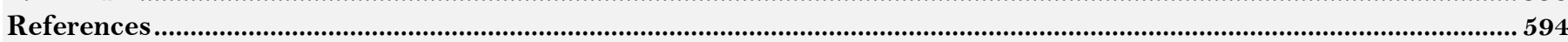




\section{Contribution of this paper to the literature}

This study contributes to existing literature by investigating the attitudes of academicians towards sports at Firat University, 191 academicians participated in the investigation as part of our study.

\section{Introduction}

Although the word "sport" comes from English, it originated not from England, actually comes from Latin. It is also derived from the words disportare, which means to separate or bring them together in Latin. It was originally pronounced as desport and disport, while in the 17th century it was pronounced desport. It has become what it is today with the disposal of its first syllable due to its wide use after the 19th century (Karahuseyinoglu, 2012).

Sports, which have been in our lives since the existence of humanity, have started to gain meanings such as struggle, competition, comparison, winning and losing as it was once used as a struggle for survival. It is stated that the sport has many physiological, psychological, educational and social benefits to individuals (Atalı et al., 2018). He said that being psychologically and physically healthy would be at peace with oneself and give positive energy to his environment. It will enable people to act in friendship as a result of their approach and behavior to the people around them as a result of living healthy lives (Türkel, 2010).

Attitude is a behavioral or situational prejudice against the object or individual in front of the person (Türkmen et al., 2016). For this reason, attitudes can take a rating as a positive attitude or negative attitude. Negative attitudes can be demonstrated by reluctance, dislike, disbelief and dissent towards an individual or object. Positive attitudes are; can be shown with feelings of desire, love and willingness (Demirhan and Altay, 2001). Attitudes come to the fore front with the culture of the region and the sense of imitation. Our attitudes, which start at a young age, may vary in later years (Kağıtçıbaşı, 2013). As the importance of time management grows in achieving personal success and goals of people today, individuals will prioritize their time planning as they change in the conditions in the future while day-to-day and instant planning is made in the first place. and create a time of recreational activity with concepts such as the ranking of values.

Recent research has shown that individuals involved in social activity are more optimistic and successful than their peers, while in some studies the risk of death seen of individuals involved in physical activity decreases (Singh et al., 2001). The two most important functions of higher education are to produce science and to train high qualified manpower. Setting off from this fact, higher education is in general defined as the universities and all other institutions affiliated to these universities which maintain, develop and disseminate scientific knowledge, and for this purpose, carry out scientific research (Akyol et al., 2018). Academicians at universities who are among the basic dynamics of society are also expected to contribute to the change and transformation of individuals in the society. Determining the sports habits of academicians who are expected to be a model for university students is important for the participation of the community in sports.

In the light of all this information, since it is thought that there is a free time activity and healthy lifestyle in sports, it is aimed in this study to examine and investigate the attitudes of academicians towards sports.

\section{Materials and Methods}

Academicians' attitudes towards sports are different, the reflections and contributions of the study, based on the basic hypothesis, to various segments of society through university students are important. Academicians' attitudes towards sports will also be effective in shaping the sports habits of university students. In this context, determining the attitudes of academicians towards sports will contribute to eliminating deficiencies and disruptions in this field and making plans to be developed.

The sampling of this study comprised of 191 randomly selected academicians at Firat University in the 20182019 academic year. Personal Information form (Gender, age, title, academic year and sports status) and Attitude Scale for Sports (Koçak, 2014) were used to determine the attitudes of the academicians participating in the study towards sports. The scale developed consists of 22 items and 3 sub-dimensions. There are 12 substances in the subdimension of psychosocial development, 6 in the physical development sub-dimension and 4 in the mental development sub-dimension. Scale Likert type is designed in the type of 5 grading and "(1) I Don't Agree at All, (2) I Agree Less, (3) Moderately Agree, (4) I agree, and (5) I agree fully". In reliability analyses, it was determined that the whole and all sub-dimensions of the scale were reliable. Statistical computer package program was used in calculating the data. Frequency of variables (f) and percentage (\%) distributions have been calculated. It was checked by skewness and kurtosis tests to determine whether the data was distributed normally. As a result of these tests and controls, the data of the study were found to be parametric. For this reason, $t$ test and variance analysis (Anova) test was used. Tukey test results were used to determine which groups the difference was among the results with significant differences. The error level in the study was taken as $p<0.05$.

\section{Findings}

In this section, the findings of the variables of the study are given. The findings showing the distribution of academicians in our research according to their qualifications were examined and interpreted.

When the age groups of academicians were examined; the largest participation was between 26-35 years (38.7\%), the minimum participation was 55 years old and above (11\%). The $69.1 \%$ of academicians are male (132) and $30.9 \%$ are women. The proportion of employees as research assistants and lecturers is $23.0 \%$ which is higher than other titleholders. Professors showed the lowest participation with $11.5 \%$. It was observed that $53.9 \%$ of academicians participated in a regular sports activity, but $46.1 \%$ did not participate regularly in any sports activity. When the academic year of academicians is examined, it is observed that $39.8 \%$ have academic careers between $0-$ 10 years, $27.7 \%$ between $10-20$ years, $21.5 \%$ between $21-30$ years and $11 \%$ have academic careers of 31 years and more. 


\begin{tabular}{l|c|c}
\multicolumn{3}{|c}{ Table-1. Distribution table of demographic characteristics. } \\
\hline Age & $\mathbf{N}$ & $\mathbf{\%}$ \\
\hline 26-35 Years & 74 & 38.7 \\
36-45 Years & 51 & 26.7 \\
46-55 Years & 45 & 23.6 \\
55 Years and older & 21 & 11.0 \\
Total & 191 & 100 \\
\hline Gender & $\mathbf{N}$ & $\mathbf{\%}$ \\
\hline Female & 59 & 30.9 \\
Male & 132 & 69.1 \\
Total & 191 & 100 \\
\hline Title & $\mathbf{N}$ & $\mathbf{\%}$ \\
\hline Research assistant & 44 & 23.0 \\
Lecturer & 44 & 23.0 \\
PhD Academic member & 38 & 19.9 \\
Associate professor & 43 & 22.5 \\
Professor & 22 & 11.5 \\
Total & 191 & 100 \\
\hline Sports situation & $\mathbf{N}$ & $\mathbf{\%}$ \\
\hline No & 88 & 46.1 \\
Yes & 103 & 53.9 \\
Total & 191 & 100 \\
\hline Academic study year & $\mathbf{N}$ & $\mathbf{\%}$ \\
\hline Up to 10 Years & 76 & 39.8 \\
10-20 Years & 53 & 27.7 \\
2 1-30 Years & 41 & 21.5 \\
31 Years and above & $\mathbf{2 1}$ & 11.0 \\
Total & 191 & 100 \\
\hline Sour Indent & & \\
\hline
\end{tabular}

Source: Independent variable; N (191).

Table-2. General average table of the attitude scale for sport.

\begin{tabular}{l|c|c}
\hline Attitude for sport & $\mathbf{N}$ & $\overline{\boldsymbol{x}}$ \\
\hline General avarage & 191 & 3.93 \\
\hline Sub-dimensions & $\mathbf{N}$ & $\overline{\boldsymbol{x}}$ \\
\hline Psychosocial development & 191 & 3.98 \\
\hline Physical development & 191 & 4.08 \\
\hline Mental development & 191 & 3.53 \\
\hline Source: Dependent variable: Attitude for sport. & \multicolumn{2}{|}{}
\end{tabular}

In the investigation of Table 2 Within the scale of 1 to $5, \bar{x}=3.86$, mental development sub-dimension, $\bar{x}=3.53$, psychosocial development sub-dimension $\bar{x}=3.98$ and physical development sub-size with an average of $\bar{x}=4.08$, academicians' attitude levels towards sports (5) were close to five.

\begin{tabular}{|c|c|c|c|c|c|c|}
\hline Attitude for sport & Gender & $\mathbf{N}$ & $\overline{\boldsymbol{x}}$ & Ss & $\mathbf{T}$ & $\mathbf{P}$ \\
\hline \multirow{2}{*}{ General avarage } & Female & 59 & 3.91 & .426 & -.244 & .807 \\
\hline & Male & 132 & 3.93 & .588 & -.275 & .783 \\
\hline Sub-dimensions & Gender & $\mathrm{N}$ & $\bar{x}$ & Ss & $\mathrm{T}$ & $\mathrm{P}$ \\
\hline \multirow{2}{*}{$\begin{array}{l}\text { Psychosocial } \\
\text { development }\end{array}$} & Female & 59 & 4.00 & .492 & .182 & .856 \\
\hline & Male & 132 & 3.98 & .610 & & \\
\hline \multirow{2}{*}{$\begin{array}{l}\text { Physical } \\
\text { development }\end{array}$} & Female & 59 & 4.12 & .565 & .698 & .486 \\
\hline & Male & 132 & 4.06 & .609 & & \\
\hline \multirow{2}{*}{$\begin{array}{l}\text { Mental } \\
\text { development }\end{array}$} & Female & 59 & 3.35 & .796 & -1.860 & .064 \\
\hline & Male & 132 & 3.61 & .939 & & \\
\hline
\end{tabular}

Table-4. Comparison of attitude scale sub-dimensions by age groups.

\begin{tabular}{|c|c|c|c|c|c|c|c|}
\hline Sub-dimensions & Age & $\mathbf{N}$ & $\overline{\boldsymbol{X}}$ & Ss & $\bar{F}$ & $\mathbf{P}$ & Turkey \\
\hline \multirow{5}{*}{ Psychosocial development } & 26-35 Years & 74 & 4.01 & .619 & .075 & .974 & \\
\hline & 36-45 Years & 51 & 3.96 & .596 & & & \\
\hline & 46-55 Years & 45 & 3.98 & .539 & & & \\
\hline & 55 Years and above & 21 & 3.99 & .460 & & & \\
\hline & Total & 191 & 3.98 & .575 & & & \\
\hline \multirow{5}{*}{ Physical development } & 26-35 Years & 74 & 4.10 & .602 & .944 & .421 & \\
\hline & 36-45 Years & 51 & 4.04 & .666 & & & \\
\hline & 46-55 Years & 45 & 4.16 & .517 & & & \\
\hline & 55 Years and above & 21 & 3.91 & .541 & & & \\
\hline & Total & 191 & 4.08 & .595 & & & \\
\hline \multirow{5}{*}{ Mental development } & 26-35 Years ${ }^{A}$ & 74 & 3.26 & .962 & 3.859 & .010 & \\
\hline & $36-45$ Years $^{B}$ & 51 & 3.72 & .852 & & & A-B \\
\hline & $46-55$ Years & 45 & 3.68 & .783 & & & \\
\hline & 55 Years and above & 21 & 3.72 & .869 & & & \\
\hline & Total & 191 & 3.53 & .903 & & & \\
\hline
\end{tabular}


In the investigation of Table 3; although the average attitude of men towards sports $(\bar{x}=3.93)$ was higher than that of women, the difference was not statistically significant. The difference between the participants' psychosocial development, physical development and mental development sub-dimensions and gender variable was not considered statistically significant $(\mathrm{p}>0.05)$.

In Table 4, the attitudes of the academicians in the study towards sports are between their lower dimensions and the age level variable, those between the age of 26-35 in the sub- dimension of mental development and those between the ages of $36-45$ the difference is significant $(\mathrm{p}<0.05)$. Difference in other sub-dimensions was not considered statistically significant.

Table-5. Comparison of the sub-dimensions of the attitude scale towards sports with a sports participation axis.

\begin{tabular}{l|c|c|c|c|c|c}
\hline Sub-dimensions & Status of regularly exercise & $\mathbf{N}$ & $\boldsymbol{\boldsymbol { x }}$ & $\mathbf{S s}$ & $\mathbf{T}$ & $\mathbf{P}$ \\
\hline \multirow{2}{*}{$\begin{array}{l}\text { Psychosocial } \\
\text { development }\end{array}$} & No & 88 & 3.85 & .470 & -3.004 & .003 \\
\hline \multirow{2}{*}{$\begin{array}{l}\text { Physical } \\
\text { development }\end{array}$} & Yes & 103 & 4.10 & .632 & & \\
\hline \multirow{2}{*}{\begin{tabular}{l} 
Mental development \\
\cline { 2 - 7 }
\end{tabular}} & No & 88 & 4.11 & .562 & .758 & .449 \\
\cline { 2 - 7 } & Yes & 103 & 4.05 & .623 & & \\
\hline \multirow{2}{*}{ Nource: Dependent varible }
\end{tabular}

Source: Dependent variable: Attitude for sport.

In Table 5 was examined, it was determined that there was a statistically significant difference between the participants' psychosocial development and mental development sub-dimensions and the exercise status variable $(\mathrm{p}<0.05)$. The difference in the physical development sub-dimension was not considered statistically significant.

Table-6. Comparison of the sub-dimensions of the attitude scale towards sports with a title axis.

\begin{tabular}{|c|c|c|c|c|c|c|c|}
\hline Sub-dimensions & Title & $\mathbf{N}$ & $\bar{x}$ & Ss & $\mathbf{F}$ & $\mathbf{P}$ & Tukey \\
\hline \multirow{6}{*}{ Psychosocial development } & Research Asistant $^{\mathrm{B}}$ & 44 & 4.13 & .613 & 4.237 & .003 & \\
\hline & Lecturer $^{\mathrm{A}}$ & 44 & 3.69 & .545 & & & \\
\hline & $\mathrm{PhD}$ academic member $\mathrm{C}$ & 38 & 4.03 & .463 & & & $\mathrm{~A}-\mathrm{B}, \mathrm{C}, \mathrm{D}, \mathrm{E}$ \\
\hline & Associate professor ${ }^{\mathrm{D}}$ & 43 & 4.03 & .566 & & & \\
\hline & Professor $^{\mathrm{E}}$ & 22 & 4.12 & .587 & & & \\
\hline & Total & 191 & 3.98 & .575 & & & \\
\hline \multirow{6}{*}{ Physical development } & Research Asistant ${ }^{\mathrm{B} B}$ & 44 & 4.20 & .558 & 4.563 & .002 & \\
\hline & Lecturer $^{\mathrm{A}}$ & 44 & 3.83 & .613 & & & \\
\hline & PhD academic member & 38 & 3.93 & .720 & & & $\mathrm{~A}-\mathrm{B}, \mathrm{C}$ \\
\hline & Associate Professor ${ }^{\mathrm{C}}$ & 43 & 4.25 & .469 & & & \\
\hline & Professor & 22 & 4.22 & .403 & & & \\
\hline & Total & 191 & 4.08 & .595 & & & \\
\hline \multirow{6}{*}{ Mental development } & Research Asistant $^{\mathrm{B}}$ & 44 & 3.51 & .864 & 7.291 & .000 & \\
\hline & Lecturer $^{\mathrm{A}}$ & 38 & 2.99 & .902 & & & \\
\hline & $\mathrm{PhD}$ academic member ${ }^{\mathrm{C}}$ & 43 & 3.61 & .833 & & & $\mathrm{~A}-\mathrm{B}, \mathrm{C}, \mathrm{D}, \mathrm{E}$ \\
\hline & Associate Professor ${ }^{\mathrm{D}}$ & 22 & 3.81 & .831 & & & \\
\hline & Professor $^{\mathrm{E}}$ & 191 & 3.98 & .761 & & & \\
\hline & Total & 44 & 3.53 & .903 & & & \\
\hline
\end{tabular}

Source: Independent variable: Attitude for sport.

In Table 6 when the attitudes of the academicians participating in the study were examined in the subdimensions and title level variable, those who were lecturers of the title of psychosocial development and the title research assistant, $\mathrm{PhD}$ academic member, there was a statistically significant difference between associate professors and professors. There has been a statistically significant difference between those who are lecturers of the title of physical development sub-dimension and those whose title is research assistant and associate professor. There has been a statistically significant difference between those who are lecturers of the title in the subdimension of mental development and those who are research assistants, $\mathrm{PhD}$ academic member, associate professors and professors $(\mathrm{p}<0.05)$.

Table-7. Comparison of the sub-dimensions of the attitude scale towards sports on the axis of the working year.

\begin{tabular}{|c|c|c|c|c|c|c|c|}
\hline Sub-dimensions & Academic study year & $\mathbf{N}$ & $\overline{\boldsymbol{x}}$ & Ss & $\mathbf{F}$ & $\mathbf{p}$ & Tukey \\
\hline \multirow{5}{*}{$\begin{array}{l}\text { Psychosocial } \\
\text { development }\end{array}$} & Up to 10 years & 152 & 3.95 & .611 & 1.089 & .355 & \\
\hline & 10-20 years & 106 & 3.91 & .525 & & & \\
\hline & 21-30 years & 82 & 4.11 & .594 & & & \\
\hline & 31 years and above & 42 & 4.04 & .518 & & & \\
\hline & Total & 382 & 3.98 & .575 & & & \\
\hline \multirow{5}{*}{$\begin{array}{l}\text { Physical } \\
\text { development }\end{array}$} & Up to 10 years & 152 & 4.08 & .584 & 1.803 & .148 & \\
\hline & $10-20$ years & 106 & 3.98 & .673 & & & \\
\hline & 21-30 years & 82 & 4.25 & .507 & & & \\
\hline & 31 years and above & 42 & 3.99 & .551 & & & \\
\hline & Total & 382 & 4.08 & .595 & & & \\
\hline \multirow{5}{*}{ Mental development } & Up to 10 years ${ }^{A}$ & 152 & 3.25 & .873 & 5.653 & .001 & \\
\hline & $10-20$ years & 106 & 3.57 & .838 & & & \\
\hline & 21-30 years ${ }^{\mathrm{B}}$ & 82 & 3.82 & 1.008 & & & $\mathrm{~A}-\mathrm{B}, \mathrm{C}$ \\
\hline & 31 years and above $\mathrm{C}^{\mathrm{C}}$ & 42 & 3.92 & .623 & & & \\
\hline & Total & 382 & 3.53 & .903 & & & \\
\hline
\end{tabular}

Independent variable: Attitude for sport. 
In Table 7 when the attitudes of the academicians participating in the study were examined in the subdimensions of their attitudes towards sports and the variable of academic seniority, those with seniority levels up to 10 years in the mental development sub-dimension and those who had seniority of 21-30 years and 31 years there was a statistically significant difference between. The difference in other sub-dimensions was not considered statistically significant $(\mathrm{p}>0.05)$.

\section{Results}

191 academicians participated in the study who works at Firat University, which aims to determine the attitudes of academicians towards sports. More than half of academicians are men. As with other areas of business, the majority of men in the academic community is expected. The proportion of researchers and lecturers (23.0\%) is higher than other title holders. Those who hold the title of professor are represented at the lowest rate at $11.5 \%$. When the academic year of academicians is examined, it is observed that $39.8 \%$ of them have work years between 0-10 years, $27.7 \%$ have work years between $10-20$ years, $21.5 \%$ have $21-30$ years and $11 \%$ have 31 years or more.

It was determined that $53.9 \%$ of academicians participated regularly in one activity and $46.1 \%$ did not participate regularly in any sports activity. According to Köksalan and Tel (2008) study on faculty members, it was stated that $64.1 \%$ of the participants were always, frequently, occasionally actively involved in sports. Similarly, in a different study that 200 academicians joined; $66 \%$ of academicians regularly participate in sports (Atasever and Çolak, 2019). In a different study, which investigated the regular participation of academicians in sports, $51.9 \%$ stated that they participated in sporting activities on a regular basis (Uluoz et al., 2017). Academicians' participation in sports is not expected In Tukey, but the rate is not low. It was observed that the attitudes of academicians towards sports were as high as $\bar{x}=3.93$ in 1 to 5 scala. More than half of academicians regularly participate in sporting activity is related to the high attitude value. It should be noted that attitudes are shaped as a result of various activities transformed into habits. Atalı and his colleagues in 2018, different faculty students' total attitude points averages for the sport has been determined $\bar{x}=4.14$ (Atalı et al., 2018). Attitudes towards sports were observed to not differ much in the sub-dimensions of the situation. It was observed that participation in regular sporting activity had a greater effect on physical development sub-dimension scores because the highest point average among the sub-dimension was in physical development $(\bar{x}=4.08)$.

In comparing the gender-based sub-dimensions of the attitude scale of the academicians participating in the study; the difference between the participants' psychosocial development, physical development and mental development sub-dimensions and gender variable was not considered statistically significant. (Keskin, 2015), Bostancl et al. (2005), Efek et al. (2018), Balyan et al. (2012) which was in parallel with our study, stated that there is no statistically significant difference between gender variable and attitude towards sports in their studies. In addition, Atalay (2016) have conducted studies on university students that gender variance is not a decisive factor in attitude towards sports (Atalay, 2016). However, Chung and Phillips (2002) said that female students' attitudes towards sports were higher than male students in their work on students' attitudes towards physical education. Similarly, in the studies conducted by Türkmen et al. (2016) on university students, it is stated that gender is a decisive factor in attitude towards sports (Türkmen et al., 2016). The study of university students stated that gender is decisive in attitude towards sports and in favor of men (Efek, 2019).

When the average scores of the academicians participating in the study from the sub-dimensions of attitude scale towards sports were examined according to age groups; There was a statistically significant difference those between the age of 26-35 and those between the age of 36-45 years of age in the lower dimension of mental development. Difference in other sub-dimensions was not considered statistically significant. Academicians between the ages of 36-45 have higher attitude scores for sports than academics between the ages of 26 and 35 . It is observed that the attitudes of younger academicians towards sports are lower in proportion to academicians whose score averages are higher than those who are older in all sub-dimensions. In a study that contrasted with our study, Türkmen et al. (2016) found no significant difference between students' attitudes towards sports and age in the study of sports attitudes for university students. Turkmen and friends' study on university students, it can be said that the students differ with our work due to the lack of their own economic freedom and the lack of age range.

When the comparison of the sub-dimensions of the attitude scale of the academicians participating in the study on the axis of the state of sports is examined; there was a statistically significant difference between the participants' psychosocial development and mental development sub-dimensions and the exercise status variable. The difference in the physical development sub-dimension was not considered statistically significant. However, Atalı and his friends in their work; university students who play sports and do not play sports have stated that there is no significant difference between their attitude sub-dimensions (Atall et al., 2018). It is observed that academicians who do exercise have higher attitude scores towards sports than academics who do not exercise. In a study similar to our study, Singh and Devi (2013) examined students' attitudes towards sports. As a result of the study, they found that students who played sports had a high attitude score than students who did not play sports. As a result of the study, they found that students who do exercises had a high attitude score than students who did not do exercises. We can also say that the reason for this is that the individuals who do exercises are aware of the mental, physical and psychological contributions of sports and that the individuals who do not do exercises are not in this consciousness.

When the academicians participating in the study were examined according to the comparison of the lower dimensions of the attitude scale towards sports with a title axis; there was a statistically significant difference between those who were lecturers of the sub-dimension of psychosocial development and those whose title was research assistant, $\mathrm{PhD}$ faculty member, associate professor and professor. There has been a statistically significant difference between those who are lecturers of the title of physical development sub-dimension and those whose title is research assistant and associate professor. There has been a statistically significant difference between those who are faculty lecturers of the title in the sub-dimension of mental development and those who are research assistants, $\mathrm{PhD}$ faculty members, associate professors and professors. When the attitude scores for sports are examined, it is seen that the attitude scores of the lecturers have lower scores in all the sub-dimensions compared to other titles. 
The reason for this is that the majority of the lecturers in our surveys are non-sports and the situation of doing exercise directly affects attitude scores towards sports, so the lecturers can be told that attitude scores are low. When the academicians participating in the study were examined according to the comparison of the attitude scale of the academics on the axis of the academic study year; there was a statistically significant difference between those with seniority levels up to 10 years in the sub-dimension of mental development and those with seniority of 21-30 years and 31 years above. The difference in other sub-dimensions was not considered statistically significant. When attitude scores for sports in the sub-dimension of mental development are examined, the attitude scores of academicians who have not completed 10 years in academic working years are lower than those of academics with more academic year scores. The reason for this is that being new in the profession is due to their ability to learn and develop the profession, and at the same time because academicians who are just starting the profession are constantly trying to rise up in academic titles, they are not able to devote time to sports. It can also be said that it is.

Academicians working in Firat University faculties and colleges; It was determined that there was a statistically significant difference in attitudes towards sports depending on age, title, sports status and academic study year variable. According to the gender variable, when we look at the attitudes of academicians towards sports, it is observed that there is no statistically significant difference. In line with the study findings, the attitude scores of academicians working in Firat University faculties and colleges towards sports with an average of $\bar{x}=3.98$ in the sub-dimension of psychosocial development and $\bar{x}=4.08$ in the physical development sub-dimension levels were observed to be high. In the sub-dimension of mental development, it was observed that the attitude levels towards sports were above average with an average of $\bar{x}=3.53$.

Young people who are educated by academicians working in universities will form the professional groups of our future. Sports are an indispensable element of society. Academicians' attitudes towards sports are very important. Instructors are among the people who need to be looked up to for students. Academicians' attitudes towards sports benefit them physically and mentally, students will also be indirectly affected by this contribution. When studies that are similar to our study are examined, the sample of the studies is generally based on the students and since there are no studies in terms of the attitudes of academicians towards sports, the academicians have been implemented. For this reason, it is thought that our study on academicians will contribute to sports psychologists, academicians, sports experts and sports science.

\section{References}

Akyol, B., K. Yılmaz, B. Çavuş and V. Aksoy, 2018. The problems of higher education in Turkey according to the views of academician administrators. Turkish Studies Educational Sciences, 13(11): 111-131.Available at: 10.7827/TurkishStudies.

Atalay, A., 2016. The analysis on sport attitudes of students at high school education in Turkey. Educational Research and Reviews, 11(5): 194-203.Available at: https://doi.org/10.5897/err2015.2613.

Atalı, L., M. Uzuner, E. Çolak and B. Bayazıt, 2018. Examination of the attitudes of the students who are related to sports from different faculties towards sport Kocaeli university example. Journal of Social and Humanities Sciences Research, 5(30): 4428-4434.

Atasever, T. and E. Çolak, 2019. The investigatıon of expectations and opinions about recreations and sporty habits of the academic staff at university of Kocaeli. Journal of Sport and Recreation Researches, 1(1): 21-34.

Balyan, M., B.K. Yerlikaya and O. Kiremitçi, 2012. Attitude towards the physical education course of primary 2 nd grade studen ts of different sporting activities. Effects on social skills and self-sufficiency levels. Selçuk University Journal of Physical Education and Sport Science, 14(2): 196-201.

Bostanc1, H., G. Demirhan and Y. Bulca, 2005. In: Comparison of primary school students' attitude toward physical education lesson. The 46'th ICHPER*SD Anniversary World Congress, November, Istanbul No.186- 187.

Chung, M. and D.A. Phillips, 2002. The relationship between attitude toward physical education and leisure-time exercise in high school students. Physical Educator, 59(3): 126-138.

Demirhan, G. and F. Altay, 2001. 2. Attitude scale of 1st grade high school students on physical education and sports. Journal of Sports Science, 12(2): 9-20.

Efek, E., 2019. Examining the relationship between the moral development levels of duzce university students who study in different faculties and sports and their attitudes towards sports. Journal of Social and Humanities Sciences Research, 6(43): 2967-2975.

Efek, E., Ö. Sivirikaya and R. Sadık, 2018. Investigation of the students relations between moral levels and sports attitudes in university of sports science. Journal of Social and Humanities Sciences Research, 5(30): 4428-4434.

Kağıtçıbaşı, Ç., 2013. Nowadays human and human beings: Introduction to social psychology. Istanbul: Evrim Yayınevi.

Karahuseyinoglu, M.F., 2012. Turkish sports on a global axis. Kum Saati Yayınları. pp: 43, Istanbul.

Keskin, Ö., 2015. Examining the attitudes of middle school students to physical education courses according to some variables: Sample of the sakarya province. The Thesis of the Master. University of Sakarya.

Koçak, F., 2014. Undergraduate students's attitudes towards sport: A scale development study. SPORMETRE Journal of Physical Education and Sports Sciences, 12(1): 59-69.

Köksalan, B. and M. Tel, 2008. Sociological examination of sports activities of faculty members sample of Eastern Anatolia. Ph.D. Thesis Firat University. Elazı $\breve{g}$.

Singh, N.P., G.E. Fraser, S.F. Knutsen, K.D. Lindsted and H.W. Bennett, 2001. Validity of a physical activity questionnaire among AfricanAmerican seventh-day adventists. Journal of Medicine and Science in Sport and Exercise, 33(3): 468-475.Available at: https://doi.org/10.1097/00005768-200103000-00021.

Singh, R.C. and K.S. Devi, 2013. Attitude of higher secondary level student towards games and sports. International Journal of Physical Education, Fitness and Sports, 2(4): 80-85.Available at: https://doi.org/10.26524/13421.

Türkel, H., 2010. Examining the relationship between the level of participation of primary school students in sportive activity and social cohesion and communication skills. Unpublished Ph.D. Thesis Erciyes University. Kayseri.

Türkmen, M., Y. Abdurahimoğlu, S. Varol and M. Gökdağ, 2016. The attitudes of the students attending to faculty of islamic sciences towards sports [The sample of Bartın University]. International Journal of Contemporary Educational Studies, 2(1): 48-59.

Uluoz, E., C.Y. Yılmaz and Z.F. Dinç, 2017. Examination of the participation status of academicians working in different faculties in physical activity. International Journal of Cultural and Social Research, 3(Special Issue 2): 326-336. 